УДК 378.046.4:004 (045)

DOI: $10.37026 / 2520-6427-2021-108-4-44-49$
Олександра СОЛОГУБ,

доктор філософіi

зі спеиіальності «Освітні, педагогічні науки», стариий викладач кафедри теорії та методик природничо-математичних дисииплін і технологій Хмельничького обласного інституту післядипломної педагогічної освіти, м. Хмельницький, Україна ORCID: 0000-0003-4781-2973

e-mail: l.sologub@hoippo.km.ua

\title{
РЕЗУЛЬТАТИ НАУКОВО-ДОСЛІДНОЇ РОБОТИ З РОЗВИТКУ ІНФОРМАЦЙНО-КОМУНІКАЦІЙНОЇ КОМПЕТЕНТНОСТІ МЕТОДИСТІВ РЕГІОНАЛЬНИХ СЛУЖБ
}

\begin{abstract}
Анотація. У статті представлено результати науково-дослідної роботи з розвитку інформаційно-комунікаційної компетентності методистів регіональних служб у процесі підвищення кваліфікації, щзо здійснювалася на базі Хмельницького обласного інституту післядипломної педагогічної освіти впродовж 2017-2020 років. Проаналізовано дослідження, в яких окреслено питання розвитку та очінювання інформачійно-комунікаційної компетентності педагогічних працівників, побудови рамок інформаційно-комунікаційної компетентності. Схарактеризовано завдання дослідження, наведено відомості про його учасників. Представлено інструменти оцінювання рівня сформованості інформаційно-комунікаційної компетентності методистів регіональних служб, які охоплюють визначені нами компоненти компетентності (мотиваційно-ціннісний, когнітивний, операчійно-діяльнісний та дослідницько-рефлексивний), рівні (базовий, поглиблений, професійний, експертний) та індикатори з урахуванням аспектів
\end{abstract}

використання ІКТ методистами. До інструментарію увійшли як традиційні методики для дослідження рівня професіоналізму педагогічних працівників, так і розроблені нами анкети, тести, чек-листи тощо. Описано результати діагностики рівня сформованості інформаційно-комунікаційної компетентності контрольної та експериментальної груп з використанням наявного інструментарію з кожного компонента компетентності та загального показника на початку та наприкінці експерименту. Наведено результати перевірки гіпотез дослідження за допомогою критерію узгодженості Пірсона, представлено порівняння розподілів контрольної та експериментальної груп за цчим критерієм, здійснено його порівняння з критичними значеннями критерію.

Ключові слова: інформачійно-комунікачійна компетентність, підвищення кваліфікаиії, методист регіональної служби, інструменти оцінювання, критерій узгодженості Пірсона.

Oleksandra SOLOHUB,

Doctor of Philosophy (Pedagogy),

Senior lecturer of Department of Theory and Methods of Natural Mathematical Disciplines and Technologies, Khmelnitsky Regional Institute of Postgraduate Teacher Education, Khmelnitsky, Ukraine

ORCID: 0000-0003-4781-2973

e-mail: l.sologub@hoippo.km.ua

\section{RESULTS OF RESEARCH WORK ON THE DEVELOPMENT OF INFORMATION AND COMMUNICATION COMPETENCE OF METHODOLOGISTS OF REGIONAL SERVICES}

\begin{abstract}
The article presents the results of research work on the development of information and communication competence of methodologists of regional services in the process of in-service training, which was carried out on the basis of Khmelnitsky Regional Institute of Postgraduate Teacher Education during 2017-2020.

It has been analyzed research on the development and assessment of information and communication competence
\end{abstract}

of teachers, building a framework of information and communication competence. The tasks of the research are describe. The information about its participants is given. The tools for assessing the level of information and communication competence of methodologists of regional services are presented, which cover the components of competence (motivational-value, cognitive, operational-activity and research-reflective), levels (basic, advanced, professional, 
expert) and indicators that take into account the areas of use of ICT by methodologists.

The toolkit includes both traditional methods for studying the level of professionalism of teachers, as well as questionnaires, tests, checklists developed by us. It has been presented results of diagnostics of the level of formation of information and communication competence of the control and experimental groups according to the proposed tools for each component of competence and the general indicator at the beginning and end of the experiment. The verification of the reliability of the results was carried out using Pearson's Chi-Square Test. Comparison of the distributions of the control and experimental groups according to this criterion is presented, its comparison with the critical values of Pearson criterion is performed. The results of research work showed that its goal has been achieved, and the tasks have been fulfilled.

Key words: information and communication competence, in-service training, methodologist of the regional service, assessment tools, Pearson's Chi-Square Test.

Постановка проблеми. В умовах модернізації змісту освіти відповідно до Концепції реалізації державної політики у сфері реформування загальної середньої освіти «Нова українська школа» особливого значення набуває питання розвитку та оцінювання ключових компетентностей здобувачів освіти. Актуальним є питання розвитку інформаційно-комунікаційної компетентності працівників, які здійснюють професійний розвиток педагогів, особливо під час реформування районних (міських) методичних кабінетів (центрів) у центри професійного розвитку педагогічних працівників, адже одним із завдань новостворених центрів $€$ консультування вчителів щодо організації освітнього процесу засобами новітніх технологій, зокрема й дистанційних.

Аналіз наукових досліджень і публікацій. Питання розвитку та оцінювання інформаційно-комунікаційної компетентності педагогічних працівників висвітлюють у своїх дослідженнях В. Биков, О. Овчарук (2017), А. Кочарян, С. Литвинова, Н. Морзе, В. Олійник, Ю. Рамський, О. Самойленко, О. Спірін, Л. Чернікова та ін. Рамки компетентності, пов'язаної з використанням IКТ педагогічними працівниками, описують: ЮНЕСКО (Структура ІКТ-компетентності вчителів. Рекомендації ЮНЕСКО, 2019), Європейська комісія (Свропейська рамка цифрової компетентності для освітян, 2017) та ін. Складники інформаційно-цифрової компетентності вчителя відображено в документі «Професійний стандарт за професіями «Вчитель початкових класів закладу загальної середньої освіти», «Вчитель закладу загальної середньої освіти», «Вчитель 3 початкової освіти (з дипломом молодшого спеціаліста)» (2020, с. 13-15).

Однак слід зауважити, що, незважаючи на значну кількість наукових досліджень, в яких окреслено досвід розвитку інформаційно-комунікаційної компетентності педагогічних та науково-педагогічних працівників, інструментарій та результати оцінювання інформаційно-комунікаційної компетентності працівників, які здійснюють професійний супровід педагогічних працівників, висвітлені в наукових джерелах недостатньо.

Мета статті - представити результати науково-дослідної роботи з розвитку інформаційно-комунікаційної компетентності методистів регіональних служб у процесі підвищення кваліфікації, що проводилася на базі Хмельницького обласного інституту післядипломної педагогічної освіти впродовж 2017-2020 років.

Виклад основного матеріалу дослідження. У процесі науково-дослідної роботи були окреслені такі завдання: проаналізувати наукові джерела для визначення стану розробленості проблеми розвитку інформаційно-комунікаційної компетентності методистів регіональних служб; висвітлити стан організації підвищення кваліфікації методистів регіональних служб у сфері формальної та неформальної освіти; підготувати рамкову структуру інформаційно-комунікаційної компетентності методистів, відповідно до якої розробити модель розвитку інформаційно-комунікаційної компетентності методистів регіональних служб у процесі підвищення кваліфікації та технологію її впровадження; здійснити експериментальну перевірку моделі та технології; розробити методичні рекомендації для представників суб'єктів підвищення кваліфікації з розвитку інформаційно-комунікаційної компетентності методистів регіональних служб.

Експериментальна перевірка моделі та технології іiї впровадження проводилася відповідно до програми науково-дослідної роботи Хмельницького обласного інституту післядипломної педагогічної освіти. Учасниками експерименту стали 206 педагогічних працівників, об'єднані в експериментальну (104 особи) та контрольну (102 особи) групи, зокрема: 21 (10,19\%) - завідувачі Р(М)МК(Ц); 145 (70,39 \%) - методисти P(М)МК(Ц); 9 (4,37 \%) - методисти та керівники структурних підрозділів інститутів післядипломної педагогічної освіти; $1(0,49 \%)$ - заступник начальника відділу освіти; 8 (3,88 \%) - головні спеціалісти відділів освіти; 17 (8,25\%) - учителі опорних шкіл та керівники методичних об'єднань; 2 (0,97 \%) - представники адміністрації закладів загальної середньої освіти; 3 (1,47 \%) представники закладів позашкільної освіти (керівник закладу, керівник структурного підрозділу, методист).

Рівень сформованості інформаційно-комунікаційної компетентності учасників експерименту визначався відповідно до розробленої нами рамкової структури компетентності, що включає: компоненти (мотиваційно-ціннісний, когнітивний, операційно-діяльнісний, дослідницько-рефлексивний); рівні (базовий, поглиблений, професійний, експертний); індикатори з урахуванням виокремлених та описаних нами аспектів використання IКТ учасниками експерименту. Інструменти оцінювання узагальнено в таблиці 1 (Сологуб, 2021, с. 169-170). До них увійшли традиційні методики для дослідження рівня професіоналізму педагогічних працівників, а також розроблений нами авторський інструментарій: «Анкета учасника експерименту», яка включає окремі блоки, що стосуються різних компонентів компетентності та їхніх індикаторів, а також визначених нами аспектів використання методистами ІКТ у професійній діяльності; анкета «Мотивація до використання методистами IКТ в освітньому процесі» (адаптована за методикою Л. Чернікової); перелік цінностей «Оволодіння ІКТ методистом» (підготовлений за методикою М. Рокича «Ціннісні орієнтації»); тест «Медіаграмотність» (Сологуб, 2021, с. 299-325); чек-листи самооцінювання виконання учасниками практичних робіт (Сологуб, 2020; Сологуб, 2020). 
Інструменти оцінювання рівня сформованості ІК-компетентності методистів регіональних служб

\begin{tabular}{|c|c|c|}
\hline $\begin{array}{l}\text { Компоненти } \\
\text { компетентності } \\
\text { (критерії) }\end{array}$ & Індикатори & Методики оцінювання \\
\hline \multirow{3}{*}{ Мотиваційно-ціннісний } & $\begin{array}{l}\text { розуміння і ціннісне ставлення до IKT } \\
\text { та процесів інформатизації в освіті }\end{array}$ & $\begin{array}{l}\text { «Анкета учасника експерименту», блок «Ро- } \\
\text { зуміння ролі IКТ та процесів інформатизації } \\
\text { в освіті» }\end{array}$ \\
\hline & $\begin{array}{l}\text { мотивація до використання методистом } \\
\text { IКТ у професійній діяльності }\end{array}$ & $\begin{array}{l}\text { анкета «Мотивація до використання методи- } \\
\text { стами ІКТ в освітньому процесі» }\end{array}$ \\
\hline & $\begin{array}{l}\text { ієрархія ціннісних орієнтацій «Викори- } \\
\text { стання ІКТ у професійній діяльності» }\end{array}$ & $\begin{array}{l}\text { перелік цінностей «Оволодіння ІКТ мето- } \\
\text { дистом» за методикою М. Рокича «Ціннісні } \\
\text { орієнтації» }\end{array}$ \\
\hline \multirow{3}{*}{ Когнітивний } & використання IКТ у професійній діяльності & $\begin{array}{l}\text { «Анкета учасника експерименту», блок за- } \\
\text { питань «Використання IКТ у професійній } \\
\text { діяльності» }\end{array}$ \\
\hline & технологічна грамотність & $\begin{array}{l}\text { «Анкета учасника експерименту», блок за- } \\
\text { питань «Технологічна грамотність» (само- } \\
\text { оцінювання рівня володіння програмами та } \\
\text { додатками) }\end{array}$ \\
\hline & медіаграмотність & анкета «Медіаграмотність» \\
\hline \multirow{4}{*}{ Операційно-діяльнісний } & $\begin{array}{l}\text { комунікація, прагнення до взаємодії } \\
\text { з учасниками освітнього процесу }\end{array}$ & $\begin{array}{l}\text { Методика на виявлення стилю взаємодії у } \\
\text { професійній діяльності (Корольчук, 2005, } \\
\text { с. 288) }\end{array}$ \\
\hline & $\begin{array}{l}\text { сприяння розвитку ІК-компетентності } \\
\text { педагогічних працівників }\end{array}$ & $\begin{array}{l}\text { «Анкета учасника експерименту», блок за- } \\
\text { питань «Сприяння розвитку ІК-компетент- } \\
\text { ності педагогічних працівників» }\end{array}$ \\
\hline & $\begin{array}{l}\text { організація співпраці педагогічних пра- } \\
\text { цівників, оцінювання засобами IКТ для } \\
\text { покращення освітнього процесу }\end{array}$ & $\begin{array}{l}\text { «Анкета учасника експерименту», блок за- } \\
\text { питань «Організація співпраці педагогічних } \\
\text { працівників, оцінювання засобами IКТ» }\end{array}$ \\
\hline & $\begin{array}{l}\text { виконання практичних завдань професій- } \\
\text { ного спрямування з використанням IКТ }\end{array}$ & $\begin{array}{l}\text { чек-листи самооцінювання виконання прак- } \\
\text { тичних робіт }\end{array}$ \\
\hline \multirow{3}{*}{$\begin{array}{l}\text { Дослідницько- } \\
\text { рефлексивний }\end{array}$} & рефлексія, здатність до саморозвитку & $\begin{array}{l}\text { методика «Здатність педагога до самороз- } \\
\text { витку» (Бондарчук, Гавлітіна, Смольська, } \\
\text { Вронська, 2016, с. 21) }\end{array}$ \\
\hline & $\begin{array}{l}\text { підвищення кваліфікації з питань вико- } \\
\text { ристання IКТ }\end{array}$ & $\begin{array}{l}\text { «Анкета учасника експерименту», блок за- } \\
\text { питань «Підвищення кваліфікації з питань } \\
\text { використання ІКТ» }\end{array}$ \\
\hline & $\begin{array}{l}\text { здатність опановувати сучасні технології } \\
\text { в умовах цифровізацї освіти }\end{array}$ & $\begin{array}{l}\text { опитувальник «Ви та технічний прогрес» } \\
\text { (Бондарчук, 2014, с. 27) }\end{array}$ \\
\hline
\end{tabular}

Визначення рівня сформованості ІК-компетентності учасників на початку та наприкінці експерименту відбувалося за кожним компонентом (критерієм) компетентності (мотиваційно-ціннісним, когнітивним, операційно-діяльнісним та дослідницько-рефлексивним) (див. табл. 2). Аналізуючи загальні показники (див. рис.), можемо констатувати, що наприкінці експерименту відсоток учасників експериментальної групи, які мають базовий рівень сформованості інформаційно-комунікаційної компетентності, зменшився iз 40,38 \% до $15,38 \%$, зменшилася кількість учасників із поглибленим рівнем (із $35,58 \%$ до $33,65 \%$ ), значно зріс відсоток учасників із професійним рівнем (iз $16,35 \%$ до $36,54 \%$ ), майже вдвічі збільшилася кількість учасників рівня «експертний» (із 7,69 \% до $14,42 \%)$.

Для аналізу результатів експерименту було висунуто нульову та альтернативну гіпотези. Згідно
3 нульовою гіпотезою рівень ІК-компетентності учасників експерименту контрольної та експериментальної груп на початку та наприкінці експерименту статистично не відрізнявся. За альтернативною гіпотезою рівні ІК-компетентності учасників експерименту контрольної та експериментальної груп на початку експерименту статистично не відрізнялися, тоді як наприкінці експерименту рівень ІК-компетентності учасників експериментальної групи став вищим порівняно $з$ контрольною, а різниця рівнів за кожним компонентом компетентності та загальним показником - статистично значущою.

Метод перевірки висунутих нами гіпотез $\left(\chi^{2}-\right.$ критерій узгодженості Пірсона) обирався на підставі класифікації задач і методів їх розв'язання (Сидоренко, 2000, с. 34). Алгоритм його обчислення висвітлено в наукових дослідженнях Е. Сидоренко, Л. Панченко (Сидоренко, 2000, с. 123; Панченко, 2013, с. 57). 
Таблиия 2

Результати діагностики рівня сформованості ІК-компетентності учасників експерименту

\begin{tabular}{|c|c|c|c|c|}
\hline \multirow{2}{*}{$\begin{array}{c}\text { Рівні } \\
\text { ІК-компетентності }\end{array}$} & \multicolumn{2}{|c|}{ Контрольна група, \% } & \multicolumn{2}{|c|}{ Експериментальна група, \% } \\
\hline & $\begin{array}{c}\text { Початок } \\
\text { експерименту }\end{array}$ & $\begin{array}{c}\text { Кінець } \\
\text { експерименту }\end{array}$ & $\begin{array}{c}\text { Початок } \\
\text { експерименту }\end{array}$ & $\begin{array}{c}\text { Кінець } \\
\text { експерименту }\end{array}$ \\
\hline \multicolumn{5}{|c|}{ Мотиваційно-ціннісний компонент (критерій) } \\
\hline Експертний & 8,82 & 10,78 & 6,73 & 13,46 \\
\hline Професійний & 17,65 & 19,61 & 18,27 & 39,42 \\
\hline Поглиблений & 37,25 & 35,29 & 37,50 & 31,73 \\
\hline Базовий & 36,27 & 34,31 & 37,50 & 15,38 \\
\hline \multicolumn{5}{|c|}{ Когнітивний компонент (критерій) } \\
\hline Експертний & 7,84 & 7,84 & 8,65 & 14,42 \\
\hline Професійний & 16,67 & 17,65 & 18,27 & 37,50 \\
\hline Поглиблений & 37,25 & 39,22 & 34,62 & 37,50 \\
\hline Базовий & 38,24 & 35,29 & 38,46 & 10,58 \\
\hline \multicolumn{5}{|c|}{ Операційно-діяльнісний компонент (критерій) } \\
\hline Експертний & 5,88 & 6,86 & 4,81 & 10,58 \\
\hline Професійний & 16,67 & 17,65 & 14,42 & 34,62 \\
\hline Поглиблений & 33,33 & 35,29 & 33,65 & 35,58 \\
\hline Базовий & 44,12 & 40,20 & 47,12 & 19,23 \\
\hline \multicolumn{5}{|c|}{ Дослідницько-рефлексивний компонент (критерій) } \\
\hline Експертний & 6,86 & 8,82 & 8,65 & 17,31 \\
\hline Професійний & 18,63 & 19,61 & 15,38 & 33,65 \\
\hline Поглиблений & 39,22 & 40,20 & 37,50 & 30,77 \\
\hline Базовий & 35,29 & 31,37 & 38,46 & 18,27 \\
\hline
\end{tabular}

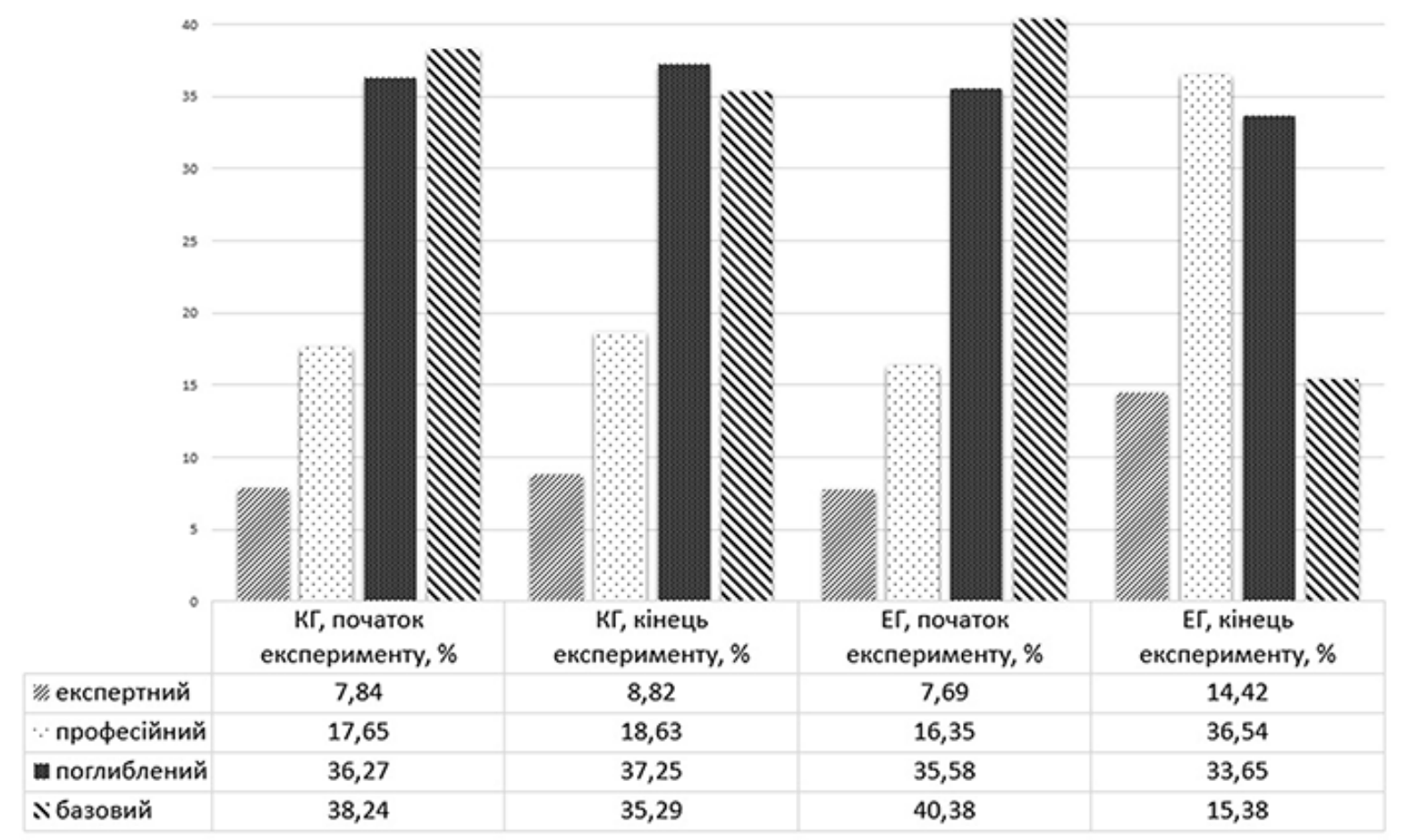

Рис. Загальні показники сформованості IК-компетентності учасників контрольної та експериментальної груп на початку та наприкінці експерименту 
Інструментом розрахунку був обраний табличний процесор Microsoft Excel, зокрема вбудована функція ХИ2ОБР, використання якої для аналізу узгодженості розподілів відображено в праці Л. Панченко (2013, c. 60$)$.
Емпіричні значення критерію Пірсона обчислювалися для порівняння контрольної та експериментальної груп $з$ кожного компонента IК-компетентності та загального показника на початку та наприкінці експерименту (див. табл. 3).

Таблиия 3

\begin{tabular}{|l|c|c|}
\hline \multirow{2}{*}{$\begin{array}{c}\text { Компоненти (критерії) } \\
\text { ІК-компетентності }\end{array}$} & \multicolumn{2}{|c|}{ Емпіричні значення критерію Пірсона $\chi^{2}$} \\
\cline { 2 - 3 } & $\begin{array}{c}\text { КГ та ЕГ на початку } \\
\text { експерименту }\end{array}$ & $\begin{array}{c}\text { КГ та ЕГ наприкінці } \\
\text { експерименту }\end{array}$ \\
\hline Мотиваційно-ціннісний & 0,323 & 14,780 \\
\hline Когнітивний & 0,217 & 23,161 \\
\hline Операційно-діяльнісний & 0,381 & 14,114 \\
\hline Дослідницько-рефлексивний & 0,711 & 11,496 \\
\hline Загальний & 0,120 & 15,631 \\
\hline
\end{tabular}

Наступним кроком було визначення критичних значень Пірсона $\chi_{\text {кр }}{ }^{2}$ за таблицями (Сидоренко, 2000, с. 260) при кількості ступенів свободи для нашого випадку, рівній 3 . Для рівня значущості $0,05 \chi_{\text {кр }}{ }^{2}=7,815$; для рівня значущості $0,01 \chi_{\mathrm{kp}}^{2}=11,346$.

Порівнюючи емпіричні значення критерію Пірсона $\chi^{2}$ із критичними, констатуємо, що емпіричні значення на початок експерименту для кожного компонента IК-компетентності та загального показника менші ніж критичне значення критерію для рівня значущості 0,05 , наприкінці експерименту всі емпіричні значення критерію більші за критичне не лише для рівня значущості 0,05 (що для педагогічних досліджень $є$ достатнім), а й для рівня значущості 0,01 .

Зважаючи на викладене вище, зауважимо, що результати статистичної перевірки дали підстави відхилити нульову та прийняти альтернативну гіпотезу дослідження.

Висновки. У процесі науково-дослідної роботи, зокрема експериментальної апробації моделі розвитку інформаційно-комунікаційної компетентності методистів регіональних служб і технології її впровадження, ми надали методистам інструментарій для ефективного виконання власних професійних функцій, які розширюються в умовах трансформації методичних установ і зростання вимог до їх працівників щодо використання сучасних технологій, підготували їх до здійснення фасилітації педагогічних працівників із питань упровадження цифрових технологій в освітній процес. Результати науково-дослідної роботи засвідчили, що ії мета досягнута, а поставлені завдання - виконані.

Перспективи подальших досліджень в означеному напрямі вбачаємо у розгляді питань щодо подальшого оновлення змісту, форм, методів підвищення кваліфікації працівників, які здійснюють супровід педагогів; підготовки андрагогів-викладачів установ післядипломної педагогічної освіти, академій неперервної освіти, інших суб'єктів підвищення кваліфікації, що здійснюють професійний розвиток педагогічних працівників у сфері формальної, неформальної та інформальної освіти, до створення цифрового навчального контенту для проведення курсів, тренінгів у дистанційному форматі; налагодження мережевої взаємодії центрів професійного розвитку педагогічних працівників із суб’єктами підвищення кваліфікації.

\section{СПИСОК ВИКОРИСТАНОЇ ЛІТЕРАТУРИ}

Биков, В. Ю., Овчарук, О. В. (2017). Оцінювання інформаційно-комунікаційної компетентності учнів та педагогів в умовах євроінтеграційних процесів в освіті: посібник. Київ: Педагогічна думка. 160 с.

Структура ИКТ-компетентности учителей. Рекомендации ЮНЕСКО. (2019). 64 c. URL: https://unesdoc. unesco.org/ ark:/48223/pf0000368076 (дата звернення: 19.08.2021).

Redecker, Ch., Punie, Y. (2017). European Framework for the Digital Competence of Educators: DigCompEdu. URL: https://publications.europa.eu/en/publication-detail/-/ publication/fcc33b68-d581-11e7-a5b9-01aa75ed71a1/ language-en (дата звернення: 19.08.2021).

Про затвердження професійного стандарту за професіями «Вчитель початкових класів закладу загальної середньої освіти», «Вчитель закладу загальної середньої освіти», «Вчитель 3 початкової освіти (з дипломом молодшого спеціаліста)»: наказ Міністерства розвитку економіки, торгівлі та сільського господарства України від 23.12.2020 р. № 2736. URL: https://nus.org.ua/wpcontent/uploads/2020/12/Nakaz_2736.pdf (дата звернення: 19.08.2021).

Сологуб, О. С. (2021). Розвиток інформаційно-комунікаційної компетентності методистів регіональних служб у процесі підвищення кваліфікації: дис. на здобуття наук. ступ. доктора філософії: 011 «Освітні, педагогічні науки». Київ: ДЗВО «Університет менеджменту освіти» НАПН України. 330 с.

Сологуб, О. С. (2020). Збірник практичних робіт до спецкурсу «Розвиток інформаційно-комунікаційної компетентності методиста». Базовий модуль. Хмельницький: Хмельницький ОІППО. 60 с.

Сологуб, О. С. (2020). Збірник практичних робіт до спецкурсу «Розвиток інформаційно-комунікаційної компетентності методиста». Професійний модуль. Хмельницький: ХОІППО. 76 с. 
Корольчук, М. С. (2005). Психологія: схеми, опорні конспекти, методики: навч. посіб. для студ. вищ. навч. закл. Київ: Ельга, Ніка-Центр. 320 с.

Бондарчук, О. І., Гавлітіна, Т. М., Смольська, Л. М., Вронська, В. М. (2016). Комплекс психодіагностичних методик дослідження професіоналізму педагогічних працівників. Київ; Рівне. 24 с.

Бондарчук, О. I. (2014). Методика дослідження особливостей психологічної готовності керівників освітніх організацій до діяльності в умовах змін. Київ. 148 с.

Сидоренко, Е. В. (2000). Методы математической обработки в психологии. Санкт-Петербург: ООО «Речь». $350 \mathrm{c}$.

Панченко, Л. Ф. (2013). Практикум по анализу данных: учебное пособие для студентов высших учебных заведений. Луганск: Луганский национальный университет имени Тараса Шевченко. 271 с.

\section{REFERENCES}

Bykov, V. Yu., Ovcharuk, O. V. (2017). Otsiniuvannia informatsiino-komunikatsiinoi kompetentnosti uchniv ta pedahohiv v umovakh yevrointehratsiinykh protsesiv v osviti [Assessment of information and communication competence of students and teachers in the context of European integration processes in education]: posibnyk. Kyiv: Pedahohichna dumka. $160 \mathrm{~s}$. [in Ukrainian].

Struktura YKT-kompetentnosty uchytelei. Rekomendatsyy YuNESKO [UNESCO ICT Competency Framework for Teachers]. (2019). 64 s. URL: https://unesdoc. unesco.org/ ark:/48223/pf0000368076 (data zvernennia: 19.08.2021). [in Russian].

Redecker, Ch., Punie, Y. (2017). European Framework for the Digital Competence of Educators: DigCompEdu. URL: https://publications.europa.eu/en/publication-detail/-/ publication/fcc33b68-d581-11e7-a5b9-01aa75ed71a1/language-en (data zvernennia: 19.08.2020). [in English].

Pro zatverdzhennia profesiinoho standartu za profesiiamy «Vchytel pochatkovykh klasiv zakladu zahalnoi serednoi osvity», «Vchytel zakladu zahalnoi serednoi osvity», «Vchytel z pochatkovoi osvity (z dyplomom molodshoho spetsialista)» [About the statement of the professional standard on professions «The teacher of initial classes of establishment of general secondary education», «The teacher of establishment of general secondary education», «The teacher on primary education (with the diploma of the junior specialist)»]: nakaz Ministerstva rozvytku ekonomiky, torhivli ta silskoho hospodarstva Ukrainy vid 23.12.2020 r. № 2736. URL: https:// nus.org.ua/wp-content/uploads/2020/12/Nakaz_2736.pdf (data zvernennia: 19.08.2021). [in Ukrainian].
Solohub, O. S. (2021). Rozvytok informatsiino-komunikatsiinoi kompetentnosti metodystiv rehionalnykh sluzhb u protsesi pidvyshchennia kvalifikatsii [Development of Information and Communication Competence of Methodologists of Regional Services in the Process of In-Service Training]: dys. na zdobuttia nauk. stup. doktora filosofii: 011 «Osvitni, pedahohichni nauky». Kyiv: DZVO «Universytet menedzhmentu osvity» NAPN Ukrainy. 330 s. [in Ukrainian].

Solohub, O. S. (2020). Zbirnyk praktychnykh robit do spetskursu «Rozvytok informatsiino-komunikatsiinoi kompetentnosti metodysta». Bazovyi modul [Collection of practical works for the special course «Development of information and communication competence of the methodologist». Basic module]. Khmelnytskyi: Khmelnytskyi OIPPO. 60 s. [in Ukrainian].

Solohub, O. S. (2020). Zbirnyk praktychnykh robit do spetskursu «Rozvytok informatsiino-komunikatsiinoi kompetentnosti metodysta». Profesiinyi modul [Collection of practical works for the special course «Development of information and communication competence of the methodologist». Professional module]. Khmelnytskyi: Khmelnytskyi OIPPO. 76 s. [in Ukrainian].

Korolchuk, M. S. (2005). Psykholohiia: skhemy, oporni konspekty, metodyky [Psychology: schemes, reference notes, methods]: navch. posib. dlia stud. vyshch. navch. zakl. Kyiv: Elha, Nika-Tsentr. 320 s. [in Ukrainian].

Bondarchuk, O. I., Havlitina, T. M., Smolska, L. M., Vronska, V. M. (2016). Kompleks psykhodiahnostychnykh metodyk doslidzhennia profesionalizmu pedahohichnykh pratsivnykiv [A set of psychodiagnostic methods for studying the professionalism of teachers]. Kyiv; Rivne. 24 s. [in Ukrainian].

Bondarchuk, O. I. (2014). Metodyka doslidzhennia osoblyvostei psykholohichnoi hotovnosti kerivnykiv osvitnikh orhanizatsii do diialnosti $\mathrm{v}$ umovakh zmin [Methods of research of features of psychological readiness of heads of the educational organizations to activity in the conditions of changes]. Kyiv. 148 s. [in Ukrainian].

Sydorenko, E. V. (2000). Metody matematycheskoi obrabotky v psykholohyy [Methods of mathematical processing in psychology]. Sankt-Peterburh: OOO «Rech». 350 s. [in Russian].

Panchenko, L. F. (2013). Praktykum po analyzu dannykh [Data Analysis Workshop]: uchebnoe posobye dlia studentov vysshykh uchebnykh zavedenyi. Luhansk: Luganskiy natsionalnyy universitet imeni Tarasa Shevchenko. 271 s. [in Russian].

Дата надходження до редакиії: 02.09.2021 p. 